\title{
Application of a technique for scenario prediction of climate change impact on the water balance components of northern river basins
}

\author{
Yeugeniy M. Gusev", Olga N. Nasonova \\ Institute of Water Problems, Russian Academy of Sciences, Gubkina St.3, 119333 Moscow, Russia. \\ ${ }^{*}$ Corresponding author. E-mail: sowaso@yandex.ru
}

\begin{abstract}
The scenario forecasting technique for assessing changes of water balance components of the northern river basins due to possible climate change was developed. Three IPCC global emission scenarios corresponding to different possible scenarios for economic, technological, political and demographic development of the human civilization in the $21^{\text {st }}$ century were chosen for generating climate change projections by an ensemble of 16 General Circulation Models with a high spatial resolution. The projections representing increments of monthly values of meteorological characteristics were used for creating 3-hour meteorological time series up to 2063 for the Northern Dvina River basin, which belongs to the pan-Arctic basin and locates at the north of the European part of Russia. The obtained time series were applied as forcing data to drive the land surface model SWAP to simulate possible changes in the water balance components due to different scenarios of climate change for the Northern Dvina River basin.
\end{abstract}

Keywords: Water balance components; Climate change scenarios; Land surface - atmosphere interactions; Physicallybased land surface modeling; Global data sets; Northern river basins.

\section{INTRODUCTION}

The influx of fresh water to the Arctic Ocean by means of runoff from the drainage area of the pan-Arctic basin represents about $50 \%$ of its net flux (Barry and Serreze, 2000). At the same time, the results from climate models generally show that the predicted global warming will be more significant in high northern latitudes, resulting in an increase of precipitation and snowmelt. Due to these factors, changes in the hydrological regime of the pan-Arctic basin may have a significant impact on both water-salt balance of the Arctic Ocean and on water balance of its drainage area, affecting the ecosystems in the region. This, in turn, can determine the rate of the positive feedback between climate change and the evolution of surrounding ecosystems. As to the impact of possible climate change on the hydrological regime of the territory, it was shown that, along with an annual volume of discharge, both the shape and timing of hydrographs of river runoff from pan-Arctic basin may change significantly. Nevertheless, investigation of the impact of global warming on the hydrological cycle and the dynamics of its components in the Arctic region has just been started. The obtained preliminary results are ambiguous and require further research, including development of more accurate techniques for hydrological projections.

Arora and Boer (2001) distinguish four approaches that are used for studying the potential impact of climate change on the hydrology and water resources of catchments and river basins: (1) application of arbitrary changes in climate inputs to hydrological models that can be considered as sensitivity studies, (2) spatial analogue techniques, (3) temporal analogue techniques, and (4) application of results from general circulation models (GCMs), either directly or by downscaling to the catchment scale. All these approaches can be applied for northern river basins.

Nowadays atmosphere-ocean global climate models (AOGCMs) represent the main tool for physically based assessment of future climate change. Besides that modern AOGCMs can be coupled with land surface parameterization schemes of different complexity and river routing models for generating runoff at each calculational grid cell and then routing it through a river network by a flow routing model to obtain streamflow at a river basin outlet. This is widely used for evaluating the performance of GCMs and for studying the impact of climate change on water resources of large river basins (e.g., Arora and Boer, 2001; Liston et al., 1994; Miller et al., 1992). Comparison of runoff hydrographs simulated by GCMs with observed ones (see, for example, Arora et al., 2001; Nohara et al., 2006) shows a poor agreement. The major reasons seem to be large errors in modelling precipitation and partitioning precipitation between evapotranspiration and runoff. To reduce biases and uncertainties of any individual GSM, a weighted ensemble mean is suggested to use for multimodel projections (Nohara et al., 2006).

Another problem is that GCMs usually operate at much larger spatial scales than hydrological applications require. To solve this problem downscaling procedure is often applied to span the gap between large-scale output generated by GCMs and regional or local scale of hydrological simulations. Downscaling techniques are generally divided into statistical and dynamical, spatial and temporal, for a review see e.g. Wilby and Wigley (1997). Each of the above technique has its own advantages and shortcomings and is more or less costly. Also, different techniques result in different spatial/temporal patterns of downscaled data that may necessitate the investigation of a number of different downscaling techniques before a suitable methodology is identified.

The alternative approach to direct application of GCMs for runoff predictions is application of their meteorological outputs as forcing data to drive hydrological models (HMs) or land surface models (LSMs). For a large river basin, which size exceeds the spatial resolution of GCMs, meteorological outputs can be used directly, while for smaller basins and catchments spatial downscaling and disaggregation techniques are used to transfer climate data from GCM scales to catchments scales (Arora and Boer, 2001). Since HMs and LSMs also contribute to uncertainty in river runoff projections, it is important that these models should adequately reproduce hydrological processes occurring in high latitudes to be applied for hydrological 
projections for northern river basins.

The objective of the present work is to describe a technique for scenario forecasting of changes in water balance components for northern river basins. Here, this problem is solved by means of application of climate change projections generated by an ensemble of 16 GCMs with a high spatial resolution on the basis of projected changes in the emission of greenhouse gases and aerosols in the atmosphere in accordance with different scenarios of social and economic development of the human civilization. The projections, representing increments of monthly values of meteorological characteristics, are used for creating 3-hour meteorological time series (this can be considered as temporal downscaling) which are applied as forcing data to drive the LSM SWAP (Soil Water - Atmosphere - Plants) (Gusev and Nasonova, 2011a) to simulate possible changes in the water balance components for the Northern Dvina River basin due to different climate change scenarios. The main advantages of the suggested technique are application of multimodel climate change projections and the advanced LSM SWAP which was widely applied for streamflow simulations in high latitudes and showed good results.

For the first time the suggested technique was described in (Gusev and Nasonova, 2013). It was applied for estimating possible changes of the water balance components (by 2063) for the Northern Dvina River basin located on the north of the European part of Russia. Four alternative scenarios of the Intergovernmental Panel on Climate Change (IPCC), belonging to the family of Special Report on Emission Scenarios (SRES) (Nebojsa et al., 2000) were used. Here, three alternative climate change scenarios of IPCC are used: IS92a, IS92c, and IS92e, which were considered as the main reference scenarios family in many publications. Hydrological projections obtained for the SRES and IS92 families are compared.

\section{METHODOLOGY}

In this section, the following issues will be described: the river basin under study, the model, the forcing data and model parameters and creation of prognostic meteorological time series for hydrological projections.

\section{The Northern Dvina River basin and its schematization}

The Northern Dvina River is one of the largest rivers of the European part of Russia belonging to the pan-Arctic basin. The area of its basin equals to $357000 \mathrm{~km}^{2}$; the average annual river runoff at the basin outlet is $309 \mathrm{~mm}$. Mean annual discharge of the Northern Dvina River is $110 \mathrm{~km}^{3}$. The Northern Dvina River starts from the merger of the Sukhona River with the Yug River (Figure 1a). The largest of its right branchs are the Vychegda River and the Pinega River, the largest left branches are the Vaga River and the Yemtsa River.

The climate in the area of the Northern Dvina River basin $\left(59-65^{\circ} \mathrm{N}, 38-56^{\circ} \mathrm{E}\right)$ is severe. The average air temperature in January equals to $-13-15^{\circ} \mathrm{C}$ (while daily temperature sometimes reaches $-45^{\circ} \mathrm{C}$ ); mean air temperature in July is $14-17^{\circ} \mathrm{C}$.

The territory of the basin is characterized by excessive wetness (mean annual precipitation varies from $650 \mathrm{~mm}$ in the north to $800 \mathrm{~mm}$ in the south-west), low solar radiation, the impact of northern seas and relatively homogeneous natural conditions. Air masses from the Atlantic Ocean slightly moderate the climate. Combination of these factors causes a short (three-four months) cool summer and long (five-six months) cold winter with stable snow cover, which lies from six months in the southern part of the basin up to seven months in the north of it.
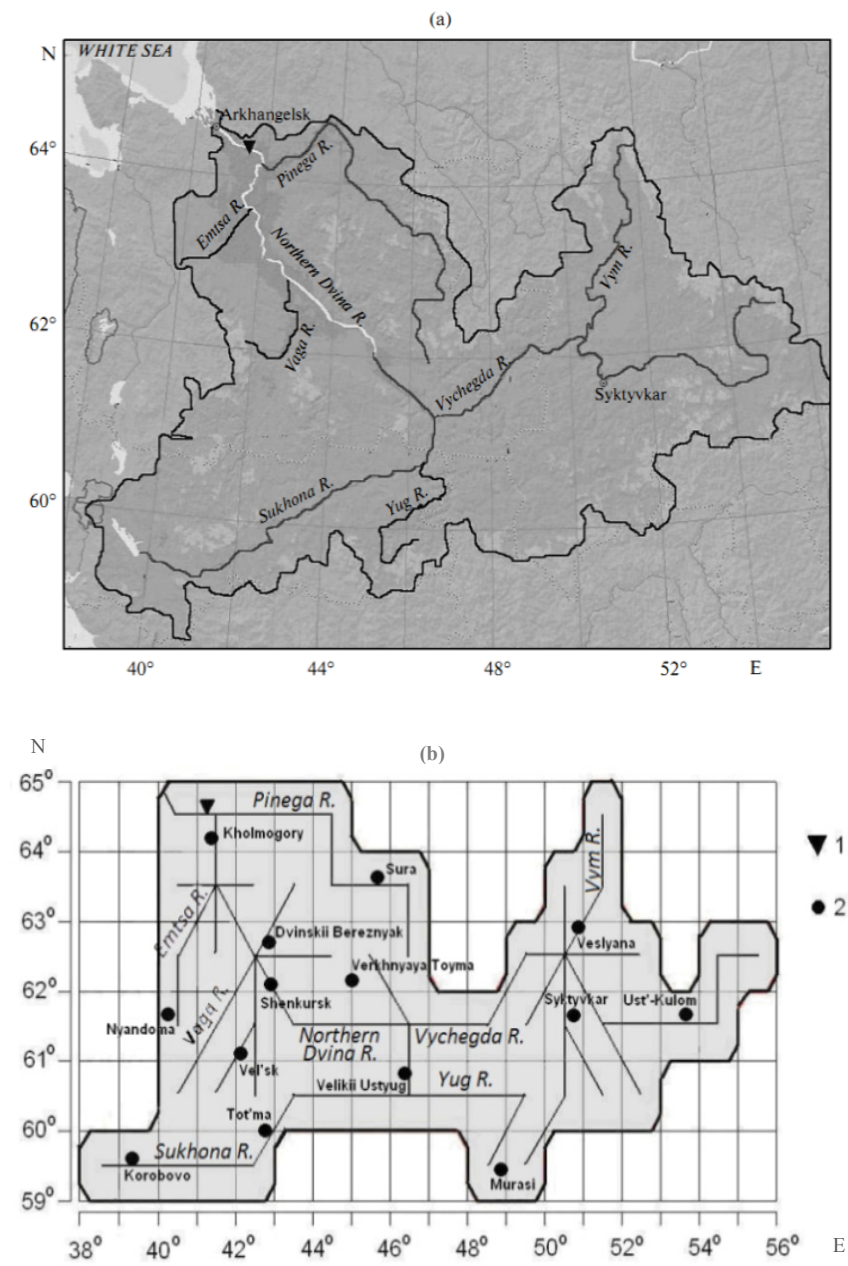

Fig. 1. (a) The Northern Dvina River basin and (b) its schematization. (1) The Ust-Pinega streamflow gage station, (2) meteorological stations.

Nearly $65-70 \%$ of annual precipitation take place during the warm period of a year. In winter, precipitation is much less, however rather large snowpack is accumulated by the beginning of spring snowmelt. Maximum snow water equivalent (SWE) is characterized by significant interannual variability. Thus, in the vicinity of Kholmogory village SWE varies from 78 to $201 \mathrm{~mm}$.

The soil within the basin is podzolic, sod-podzol and swampy-podzol, and somewhere karst occurs. Most of the basin $(\sim 80 \%)$ is covered with forest (mainly composed by pine).

The Northern Dvina River has mixed feeding with the predominance of snowmelt component. The northern rivers, where the main source of feeding is melt water, are characterized by nonuniform distribution of discharge during a year. Thus, more than a half of annual discharge occurs during the three spring months, while during the four winter months the discharge is only $2-9 \%$ of its annual volume. Rain floods are usually insignificant.

Mean annual evaporation varies from $400 \mathrm{~mm}$ in the north to $550 \mathrm{~mm}$ in the south of the basin.

For model runs the Northern Dvina River basin (up to the Ust-Pinega streamflow gage station) was represented by 62 calculational grid cells with a spatial resolution of $1^{\circ} \times 1^{\circ}$ (Figure $1 b)$. 


\section{The land surface model SWAP}

The model SWAP was described in details in a number of publications, in particular, in (Gusev and Nasonova, 2000, $2003,2004,2011 a)$. The model is based on mathematical description of the physical processes of heat and water exchange taking place in a ground water - soil - vegetation / snow cover atmosphere system, as well as on description of runoff transformation in each calculational grid cell of a basin and in a river network to obtain hydrographs at the river basin outlet. The model allows the simulation of the components of the water and heat balances of terrestrial ecosystems and river basins at different spatial scales and under different natural conditions.

The main distinctive feature of SWAP is the combination of physically-based treatment of the main processes and the rationality of used modelling technique. The latter is provided by application of analytical methods (contrary to the usual practice of using the numerical ones) to solve the systems of equations and by a relatively small number of model parameters. This allows us to avoid many problems associated with solving the numerical equations (such as instability, great consumption of computer resources and computational time, and so on) and parameter estimation.

Application of analytical methods has resulted in nontraditional structure of the SWAP model. Thus, in SWAP, a calendar year is divided into the warm and cold seasons, two separate submodels were developed for each season, and then the submodels were linked into one general model, named SWAP. The cold-season submodel is used only in the case of one of the following conditions: (1) the mean daily air temperature is below $0^{\circ} \mathrm{C}$ continuously during several days (here, not less than 7 days); (2) the land surface is covered with snow; (3) the soil freezing depth is greater than zero. Otherwise, the warm-season submodel is used.

The model includes the following hydrological processes (1) interception of rainfall/snowfall by the canopy; (2) evapotranspiration (including transpiration by plants, soil/snow evaporation, evaporation of intercepted precipitation); (3) formation of snowpack on the ground and on the trees' crowns (including snow accumulation, snow evaporation, snowmelt, water yield of snow cover, refreezing of melt water); (4) formation of surface runoff; (5) formation of drainage; (6) water infiltration into a soil; (7) water exchange between soil layers; (8) interaction between soil water and groundwater.

The SWAP model treats formation of surface runoff on the basis of both the Hortonian mechanism, according to which the surface runoff occurs when precipitation rate exceeds infiltration rate, and the Dunne mechanism. In the latter case, the surface runoff forms as a result of raising a water table depth up to the surface of the earth. The concept of saturation excess is used for parameterization of subsurface runoff. Total runoff (including surface and subsurface components) is simulated for each calculational grid cell. The next problem is a transformation of the total runoff to simulate streamflow at a catchment outlet. This is performed by a two-step approach to route the simulated runoff (1) through a calculational grid cell and (2) through a river network. In the former case, the concept of the two dimensional kinematic wave is used, while in the latter case, a river routing model is applied.

The SWAP model also treats formation of energy balance and formation of the dynamics of soil freezing and thawing depths.

The input data for SWAP include meteorological information with a temporal resolution of less than a day (usually 3 hours) and land surface parameters: soil, vegetation and topographic characteristics.

Preliminary results of simulating the hydrographs for northern rivers by the SWAP model are presented in (Gusev and Nasonova, 2011a, 2011b; Gusev et al., 2008, 2011a, 2011b).

\section{Historical meteorological data}

Meteorological data defining the upper boundary conditions for model simulations are based on 3-hour standard observations (air temperature and humidity, air pressure, wind speed, precipitation, and cloudiness), which were taken from meteorological stations located in the Northern Dvina River basin (Gusev et al., 2011b).

The required 3-hour incoming shortwave radiation was calculated using technique developed by Shmakin (1998). Application of this technique requires information on geographical latitude, solar declination, horizon closure, latitudinal and longitudinal slopes of the underlying surface (the last three quantities can be derived from topographic characteristics of grid cells of a basin) and atmospheric transparency to obtain incoming shortwave radiation for clear sky. Mean monthly transparency can be taken from (Pivovarova, 1977). Then the obtained clear sky radiation is adjusted for the total cloudiness (Gusev and Nasonova, 2011a). Incoming longwave radiation was estimated by empirical relations using observed data on air temperature at a height of $2 \mathrm{~m}$ and cloudiness (Gusev et al., 2006a).

Interpolation of meteorological data to the center of each river basin cell was performed using the kriging procedure (Gusev et al., 2008).

\section{Land surface parameters for the SWAP model}

Most of vegetation, soil and topography parameters for the Northern Dvina River basin were taken from the global data sets provided within a framework of the Second Global Soil Wetness Project (GSWP-2) (Zhao and Dirmeyer, 2003). Here, the International Geosphere-Biosphere Programme (IGBP) classification for the land surface containing 17 land surface classes was used. On the basis of information on the distribution of these classes over the basin grid cells the model specific vegetation parameters were estimated. The provided vegetation data sets were corrected to eliminate serious discrepancies and errors. Details of the correction, along with the list of vegetation parameters used in the SWAP model can be found in (Gusev et al., 2006b).

Soil parameters taken from the International Satellite LandSurface Climatology Project Initiative II (ISLSCP-II) / GSWP-2 global data sets, which, in turn, were taken from the Data Information System (IGBP-DIS). The parameters were adapted for the SWAP model and corrected to some extent to eliminate implausible values and to meet the agreement among themselves and with vegetation parameters (Gusev et al., 2006b).

Topographic characteristics, needed for the SWAP model to rout runoff through a computational grid cell, include mean altitude of grid cells and their slopes in longitudinal and latitudinal directions. The former were taken from the Earth Resources Observation Systems Data Center (EDC) database, the latter were calculated using the mean altitudes of the neighboring cells.

The obtained data differ in the accuracy, reliability and validity. To ensure a sufficiently high (according to hydrological requirements) quality of calculations some of the most important model parameters should be optimized. 


\section{Optimization of model parameters}

In the present work, in contrast to a number of other works (Gusev and Nasonova, 2011a; Gusev et al., 2008, 2011a) only the land surface parameters (without application of adjustment factors to precipitation and radiation) were optimized. A set of calibrated parameters for northern river basins was determined and proved in (Gusev et al., 2008).

Eight land surface parameters were calibrated: hydraulic conductivity at saturation $K_{0}$, soil column thickness $h_{0}$ (here, the depth from the soil surface to the upper impermeable layer), the snow-free vegetation albedo $a l b_{\text {sum }}$, the vegetation albedo in winter period (with snow on tree crowns) $a l b_{\text {win }}$, the root layer depth $h_{r}$, albedo of fresh snow $a l b_{w i n}$, and parameters controlling the transformation of runoff both within a grid cell (the Manning roughness coefficient $n$ ) and in a river channel network (effective velocity of water movement in a channel $u_{e}$ ). To reduce the number of calibrated parameters and increase their stability, instead of $K_{0}, h_{r}, a l b_{\text {sum }}$ and $a l b_{\text {win }}$ for each grid cell, the adjustment factors (taken to be constant for the entire basin) to a priori values of these parameters $\left(k_{K 0}, k_{h r}, k_{\text {albsum }}\right.$ and $k_{\text {albwin }}$, respectively) were calibrated. Besides that $h_{0}$ was represented as $k_{h 0} h_{r}$ for each grid cell, where $k_{h 0}$ is also an adjustment factor taken to be constant for the basin.

Optimization of the parameter values was performed against daily streamflow of the Northern Dvina River measured at the Ust - Pinega gage station during the period of 1986-1990. The global optimization algorithm, known as the Shuffled Complex Evolution method developed by the University of Arizona (SCE-UA), was applied for the automated search of the global optimum of an objective function (Duan et al., 1992). The objective function represented the standard deviation of calculated daily streamflow from observed one. The search of the minimum of the objective function was carried out among the calculated streamflow, for which bias did not exceed 5\%.

\section{Development of prognostic meteorological time series for the period till 2063}

Three alternative scenarios of the Intergovernmental Panel on Climate Change (IPCC) were used: the IS92a, IS92c, and IS92e. They include a wide range of assumptions relating to the intensity of greenhouse gas emissions in dependence of special policy, carried out by mankind in the field of climate impacts. The assumptions for these scenarios are mainly taken from published forecasts of the leading international organizations or from IPCC expert's analysis (Leggett et al., 1992; Nebojsa et al., 2000; Pepper et al., 1992). Most of them have been the subject of extensive scientific review.

The IS92a scenario was used as a base scenario for estimating the consequences of climate change. According to this scenario, it is supposed that the population of the Earth will reach 11.3 billion people by 2100 ; the planet-average economic growth from 1990 through 2100, with the use of both traditional and renewable energy sources, will be $2.3 \%$ per year. The S92e scenario is characterized by, among other assumptions, higher greenhouse gases emission, moderate population growth, high rates of economic growth, large intensity of fossil fuels usage and the gradual phasing out of nuclear energy. And finally, the IS92c scenario is characterized by $\mathrm{CO}_{2}$ emission dynamics, which results in decreasing the emission of greenhouse gases by the end of $21^{\text {st }}$ century below the level of 1990 . This scenario assumes the population of the Earth first to increase and then to decrease by the middle of the $21^{\text {st }}$ century, the economic growth is low, and there are strong restrictions on the use of fossil fuels.
It should be emphasized, that the present work is of methodological character and, instead of IS92 climate scenarios, any other scenarios can be used, e.g. SRES, RCT and so on.

To obtain the dynamics of meteorological and actinometrical characteristics in the $21^{\text {st }}$ century for SWAP model runs, the MAGICC/SCENGEN (Model for the Assessment of Greenhouse-Gas Induced Climate Change / Global and Regional Climate Scenario Generator) computer code (Model..., 2000) was used. It represents a generator of climatic scenarios designed for estimation of the vulnerability or adaptation of various ecosystems or biomes of the planet to climate changes.

Global projections (obtained from the implementation of a certain scenario of the social and economic development of the human population) of the evolution of the annual values of (i) carbon emission into the atmosphere, (ii) carbon dioxide concentration in the atmosphere, (iii) changes in the incoming radiation components in accordance with the increment of each constituent of greenhouse gases and aerosols in the atmosphere, and (iv) changes in the surface temperature and the ocean level for the period from 1990 to 2100 are the MAGICC output characteristics.

At the next stage the global projections should be converted into regional ones. This can be performed by different ways. Here, the aforementioned SCENGEN program complex was applied. It uses, first, the MAGICC's outputs and, second, global distributions of major meteorological elements obtained with the help of atmospheric general circulation models (GCMs) with a high spatial resolution.

As a result of the SCENGEN application to the Northern Dvina River basin, the projections of increments (relative to 1990) for mean monthly values of air temperature and humidity, precipitation, cloudiness and wind velocity corresponding to the IS92a, IS92c, and IS92e scenarios were obtained for each computational grid cell for the period of 2000-2100. It should be noted that the increments of these meteorological characteristics have quite pronounced seasonal course. It is also important that application of the SCENGEN code, allowed us to use the results from an ensemble of GCMs listed in Table 1. As it was noted in (Meleshko et al., 2003, 2004), the simulations of historical climate and seasonal climatic predictions are more successful if they are averaged over an ensemble of independent models.

Since the SWAP model runs are carried out with 3-hour time step (to take into account a diurnal course of physical processes), it is necessary to transform mean monthly values of meteorological characteristics into 3-hour values. For this purpose, calculation formulas approximating the annual course of increments of meteorological elements on the basis of information on their mean monthly increments were derived. The formulas have the following form:

$\Delta y(n, i)=\Delta T_{g l}(n) F_{y}(i)$

where $\Delta y(n, i)$ is the change in meteorological characteristic $y$ (in absolute units for air temperature and in relative units for precipitation, wind speed, air humidity, and cloudiness) for the $i$-th 3-hour time step and the $n$-th year (measured from 1990); $\Delta T_{g l}$ is the change of the global mean annual temperature for the $n$-th year (compared to the temperature in 1990); and $F_{y}(i)$ is the approximating polynomial, whose coefficients were obtained from the estimates (with the use of the SCENGEN) of mean monthly changes in the corresponding characteristic, normalized by $\Delta T_{g l}$. Figure 2 shows some examples of evolution of changes (compared to 1990) in near-surface air temperature and precipitation in the Northern Dvina River basin calculated 
Table 1. Atmospheric general circulation models of a high resolution from the SCENGEN.

\begin{tabular}{ll}
\hline $\begin{array}{l}\text { Brief model } \\
\text { title }\end{array}$ & Full model title, country \\
\hline HadCM2 & Hadley Centre Unified Model 2 Transient Ensemble-mean (UK) \\
UKTR & UK Met Office / Hadley Centre Transient (UK) \\
CSIRO-TR & Commonwealth Scientific and Industrial Research Organization, Transient (Australia) \\
ECHAM4 & European Centre / Gamburg Model 4 Transient (Germany) \\
UKHI-EQ & UK Met. Office High Resolution (UK) \\
CSIRO2-EQ & Commonwealth Scientific and Industrial Research Organization, Mark 2 (Australia) \\
ECHAM3 & European Centre / Gamburg Model 3 Transient (Germany) \\
UIUC-EQ & University of Illinois at Urbana Champaign (USA) \\
ECHAM1 & European Centre/Gamburg Model 1 Transient (Germany) \\
CSIRO1-EQ & Commonwealth Scientific and Ind. Research Org., Mark 1 (Australia) \\
CCC-EQ & Canadian Climate Centre (Canada) \\
GFDL-TR & Geophysical Fluid Dynamics Laboratory Transient (USA) \\
BMRC-EQ & Bureau of Meteorology Research Centre (Australia) \\
CGCM1-TR & Canadian Climate Centre for Modelling and Analysis 1 Transient (Canada) \\
NCAR-DOE & National Centre for Atmospheric Research (DoE) Transient (USA) \\
CCSR / NIES & Centre for Climate Research Studies / NIES (Japan) \\
\hline
\end{tabular}
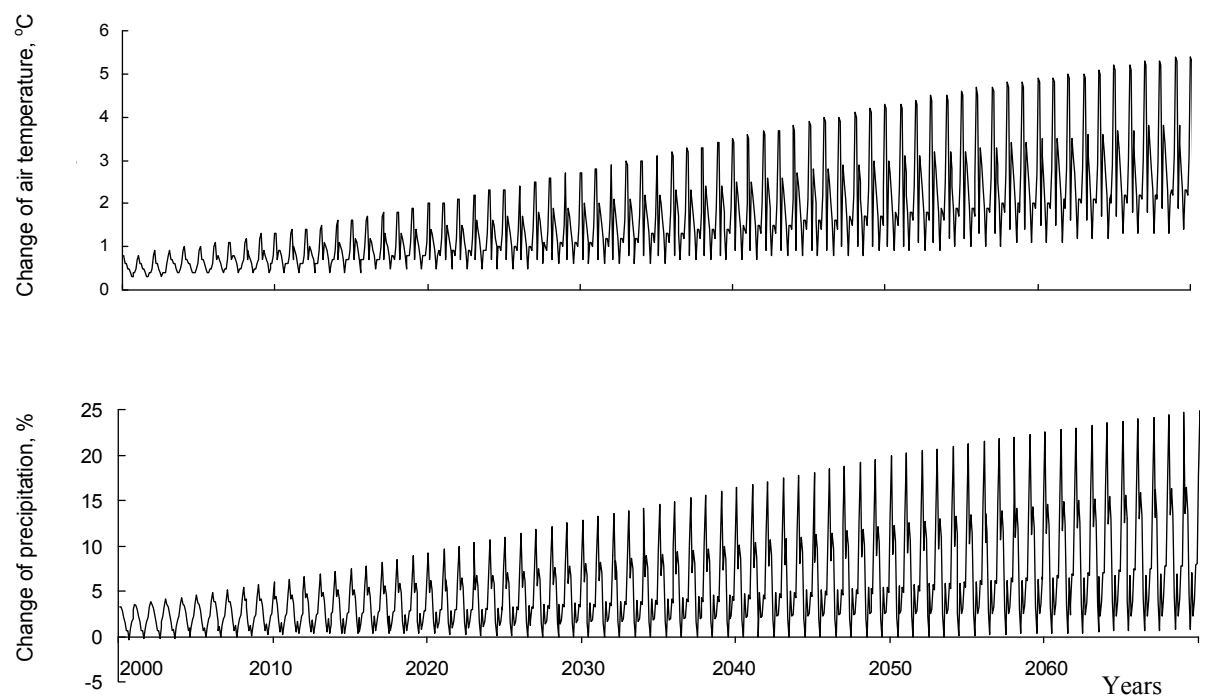

Fig. 2. Changes (as compared to 1990) of near-surface air temperature and precipitation in the Northern Dvina River basin from 2000 to 2070, in accordance with the IPCC IS92a climatic scenario.

by eq. (1) for the period from 2000 to 2070 for the IS92a scenario. Here, oscillations of changes in temperature and precipitation can be explained by that GCM-generated changes of these characteristics are sufficiently greater during the winter as compared to summer.

The above formulas make it possible to estimate long-term changes in meteorological characteristics and can be used for modelling these characteristics for the entire $21^{\text {st }}$ century in accordance with the IPCC IS92 scenarios, provided that historical time series of meteorological information (with a 3-h step) for a fairly long period (let's call it the T0-period) are available. Here, the T0-period corresponds to the period of 1968-1999. Meteorological time series for T0-period were used to obtain a realization of the stationary component for each meteorological characteristic from its temporal variation (through the elimination of the temporal trend calculated for the specified period also with the use of the MAGICC/SCENGEN code). Further, for each meteorological element, the stationary component (which reflects intra-annual, synoptic, and diurnal variabilities) was "transferred" to the projected years of the $21^{\text {st }}$ century and combined with the long-term trend of this element in the $21^{\text {st }}$ century calculated from eq. (1) for each computational cell. At each time step $i$, the combination was performed either by addition of the absolute values of $\Delta y(n, i)$ to the stationary component $y$ (for air temperature) or by multiplication of $y$ by the quantity $[1+\Delta y(n, i)]$ (for precipitation, wind speed, air humidity, and cloudiness). Such a technique allowed us to obtain one of the possible realizations of evolution of meteorological characteristics over the period of 2000-2063 in accordance with the IS92 scenarios.

As to incoming longwave radiation $R_{L W}$, its relative changes were calculated by Kirchhoff's equation (Matveev, 1979) with accounting for both contemporary air temperature and its changes in $21^{\text {st }}$ century in the region under study. Changes in incoming shortwave radiation $R_{S W}$ were derived from the global data on its decrease (due to increase of aerosol concentration in the troposphere) corrected proportionally to the ratio of local 
mean annual $R_{S W}$ in the region under consideration to the global mean annual $R_{S W}$. It should be noted that the accuracy of estimation of the impact (both direct and indirect, i.e., associated with changes in cloudiness and water-droplet sizes in clouds) of anthropogenic aerosol concentration in the troposphere on the incoming radiation is not high compared to the accuracy of estimation of the impact of other factors on the climatic system (Houghton et al., 2001), however, this will not greatly influence the final results due to smaller contribution of anthropogenic aerosols to changes in the climate system characteristics compared to other factors.

Note that, in the present work, the widespread weather generators could not be applied to obtain prognostic meteorological elements, because the number of output variables in these generators is much less than that required for LSMs (including the SWAP model).

One more issue should be considered briefly, namely, the dependence of stomatal conductance $g_{c}$ and potential transpiration of vegetation $E P$ on the carbon dioxide concentration in the ambient air $c_{a}$. In the SWAP version presented in (Gusev et al., $2011 \mathrm{~b}$ ), this dependence was not taken into account due to small changes in the concentration of atmospheric $\mathrm{CO}_{2}$ over the period under study; however, if $\mathrm{CO}_{2}$ concentration changes are substantial they should be taken into account. In SWAP, this can be done by incorporation of the dependences $g_{c}\left(c_{a}\right)$ and $E P\left(c_{a}\right)$.

Analysis of experimental data for a number of crops (see, for example, Maherali et al., 2002; Polley et al., 1997) shows that within the range of $c_{a}$ from 200 to $900 \mathrm{ppm}$, the dependence $g_{c}\left(c_{a}\right)$ can be approximated by the exponential function

$$
g_{c} / g_{c 0}=\exp \left[-\mu_{i}\left(c_{a}-c_{a 0}\right)\right]
$$

where $g_{c 0}$ is the stomatal conductance $\left(\mathrm{m} \mathrm{s}^{-1}\right)$ of phytoelements of a certain vegetation type corresponding to the present-day $\mathrm{CO}_{2}$ content in the atmosphere, which is assumed to be equal to $350 \mathrm{ppm}$, and $\mu_{i}$ is an empirical parameter depending on the vegetation type (specified by the index $i$ ) and controlling the rate of $g_{c}$-changes due to $c_{a}$-changes. The review of investigations for 23 species of woody vegetation, presented in (Field et al., 1995), show that the doubling of the $\mathrm{CO}_{2}$ concentration in the atmosphere decreases the stomatal conductance by $23 \%$ on average, while for coniferous species (Pinus radiata, Pinus taeda, Picea abies), such a decrease is only $10 \pm 2 \%$ on average. Since coniferous forests are the dominant vegetation in the Northern Dvina River basin, the latter value was accepted here for evaluation of $\mu_{i}$.

Changes in the stomatal conductance resulted from changes in the atmospheric $\mathrm{CO}_{2}$ affect the transpiration rate of vegetation. This effect was taken into account using the semiempirical theory for the description of evapotranspiration proposed by Budagovskii (Budagovskii 1981, 1989; Lozinskaya, 1988). This allowed us to derive an expression for the dependence of the potential transpiration $E P_{i}$ of the $i$-th type of vegetation on $c_{a}$ (under the same meteorological conditions) in the following form:

$$
E P_{i}=2.25 E P_{0 i} /\left\{2.0+0.25 \exp \left[\mu_{i}\left(c_{a}-c_{a 0}\right)\right]\right\},
$$

where $E P_{0 i}$ is the potential transpiration of the $i$-th vegetation type at the present-day $\mathrm{CO}_{2}$ content in the atmosphere. Equation (3) was incorporated into the transpiration block of SWAP.
It should be also noted that the land surface parameters were not changed when model simulations were performed for the $21^{\text {st }}$ century. The authors proceeded from the fact that in this predominantly forest and cold region, significant agricultural activity is not expected and values of soil hydrophysical parameters will remain the same. As to the vegetation, its morphological characteristics for the specified period will not change significantly, even with the increase of carbon sinks in this area. This can be explained by the following. As it was shown in a number of publications, including (Gusev and Nasonova, 2007), under more or less steady state of forest ecosystems (as it is in the Northern Dvina River basin) carbon sequestration occurs mainly in a soil, while carbon accumulation in living biomass is small and practically doesn't change the model parameters of vegetation. Significant succession also is not expected during the selected time interval. Therefore, the vegetation parameters for the Northern Dvina River basin can be assumed to be the same as in the modern period.

\section{RESULTS}

Simulations of the water balance components of the Northern Dvina River basin were carried out for the period of 1967-2063 for the three selected climate change scenarios. First of all let us consider the historical simulations.

\section{Evaluation of the quality of the Northern Dvina River} streamflow simulation for the historical period (1967-1998)

The quality of simulations was evaluated by means of the following goodness-of-fit statistics commonly used in hydrology (and used by the authors in (Gusev and Nasonova, 2011b; Gusev et al., 2008, 2010, 2011a, 2011b): the systematic error Bias equaled to the difference between the calculated and observed mean streamflow, the coefficient of correlation between calculated and observed values Corr, and the efficiency of simulation Eff according to (Nash and Sutcliffe, 1970).

It is commonly assumed that when Eff $>0.5$, the model adequately simulates the dynamics of the examined characteristic $x$ (when $E f f=1$, the simulation is perfect), while when $E f f<0$, the simulation of time variations in $x$ is poor (in such a case, even simple averaging of the observed values will be better than simulation). According to (Appolov et al., 1974), the accuracy of runoff forecasts can be evaluated using the following scale: the accuracy is considered to be "good" when $E f f \geq 0.75$, "satisfactory" when $0.36 \leq E f f<0.75$ and "poor" when Eff $<0.36$. As to the value of $\mid$ Bias $\mid$, estimating the quality of streamflow simulation with making use of this criterion can be based on the assumption that the systematic error in daily, monthly, and annual values of observed river streamflow is within the range of $\pm 5 \%$ (WMO, 1994) (for flood peaks, the error of measurement can be much higher). In this situation, the quality of streamflow simulation with $\mid$ Bias $\mid \leq 5 \%$ can be considered as good.

Figure 3 illustrates the hydrographs of the modeled and measured daily streamflow for the Northern Dvina River at the Ust-Pinega streamflow gage station for 1967-1998. The modeled hydrographs were obtained using the optimal values for the land surface parameters. As can be seen, the agreement between simulations and observations is good. This is confirmed by the goodness-of-fit statistics: Bias $=3 \%$, Eff $=0.83$, and Corr $=$ 0.91 

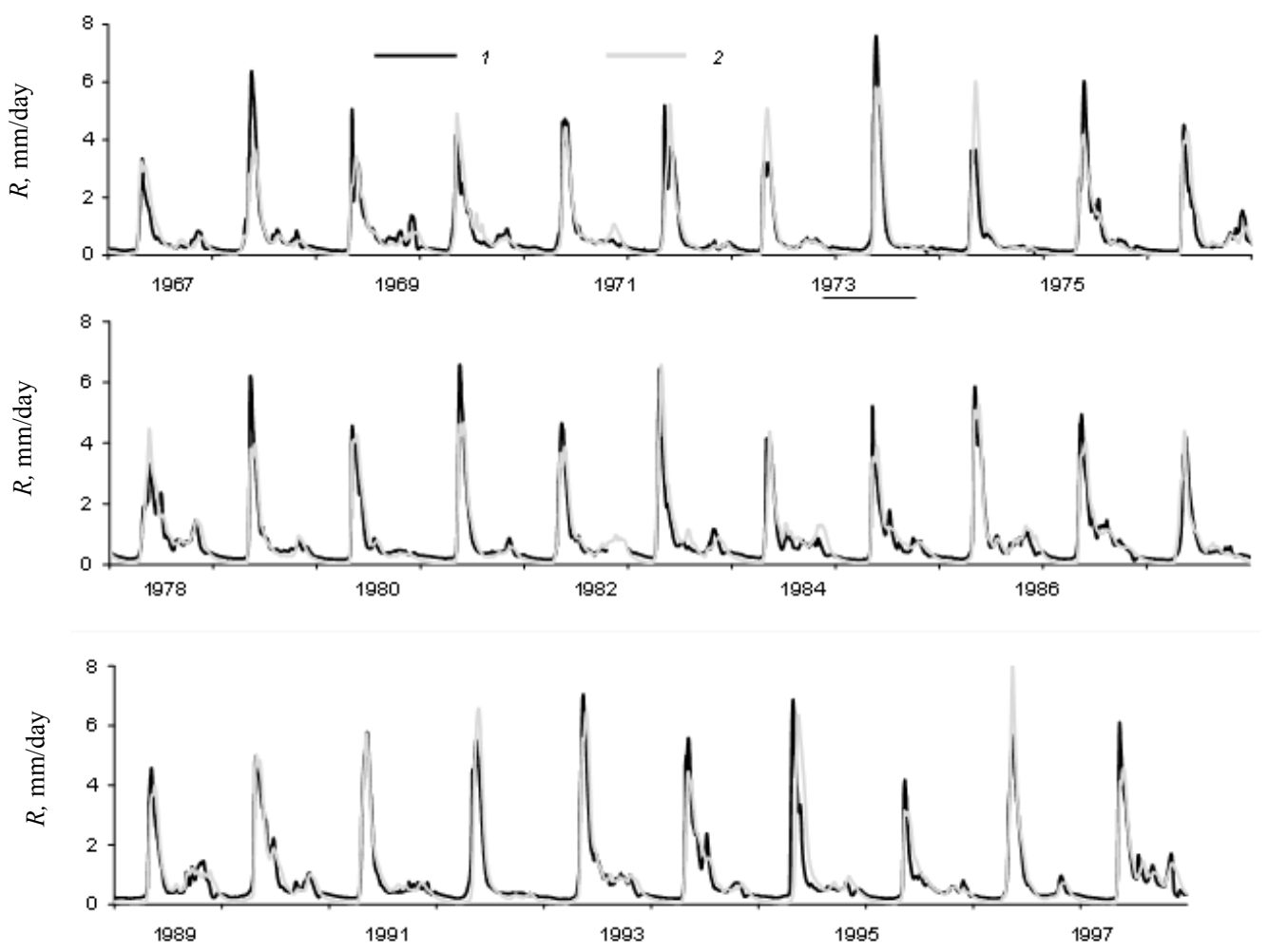

Fig. 3. Measured (1) and simulated (2) daily streamflow $R$ from the Northern Dvina River basin at the Ust- Pinega streamflow gage station in 1967-1998. Parameter calibration was carried out for 1986-1990.

The obtained results have shown that application of the LSM SWAP in conjunction with the information support, based on the global data sets of the land surface parameters (with the optimization of some parameters) and on the meteorological information measured at meteorological stations, provides a high quality simulations of daily hydrographs for the Northern Dvina River for quite a long period (i.e., for a wide range of meteorological conditions).

A large experience of working with the SWAP model has shown, that if one of the characteristics of water regime is simulated with a high accuracy, the rest characteristics are also reproduced quite adequately (Gusev and Nasonova, 2011a). This testifies that the quality of the model is fairly good. This conclusion gives the possibility to use the SWAP model (with optimized land surface parameters) for projections of the water balance component dynamics for the Northern Dvina River basin for the $21^{\text {st }}$ century.

\section{Projections of the evolution of the water balance components for the Northern Dvina River basin based on the IPCC IS92 climate change scenarios}

Before the analysis of the obtained results, the following two circumstances should be emphasized. First, as it was expected, according to our estimations the impact of the dynamics of anthropogenic aerosols on the dynamics of the water balance components up to the middle of the $21^{\text {st }}$ century is very low (the first fractions of a percent that is within the accuracy of simulation). Second, the same can be said about negligible impact of changes in the stomatal resistance caused by the change in the concentration of $\mathrm{CO}_{2}$ in the atmosphere. This is largely explained by the fact that the dominant vegetation in this area is a coniferous forest, for which an increase in the stomatal resistance due to increasing concentration of carbon dioxide, as it was aforementioned, is very low. In addition, when the transpiration is calculated, the stomatal resistance represents only one of the contributers into the total resistance to vapor transport on its way from a mesophyll of a leaf (or a needle) to a stomata, then to an intravegetation space and to the atmosphere (the last two resistances do not depend on the content of $\mathrm{CO}_{2}$ in the atmosphere). In its turn, the transpiration is only one of the components of evapotranspiration, which also consists of evaporation of intercepted precipitation, evaporation from bare soil, and evaporation from snow (both on tree crowns and at the forest floor). Evidently, changes in the concentration of $\mathrm{CO}_{2}$ in the atmosphere do not influence the last three components of the evapotranspiration. That is why the accounting for the effects of stomatal resistance change due to increase of $\mathrm{CO}_{2}$ in the atmosphere is also within the accuracy of simulation of the water balance components for the Northern Dvina River basin during the period under study.

The obtained results are presented in Figures 4-8. In Figure 4, the climatic dynamics of the water balance components for the Northern Dvina River basin from 1967 to 2063 and for the three IS92 scenarios are presented. The climatic averaging was performed over four periods: 1967-1990, 1991-2014, 2015-2038 and 2039-2063. As can be seen from the results, all three climate scenarios increase rainfall and evapotranspiration and reduce streamflow. The largest changes are observed for the IS92e scenario, while the lowest for the IS92c scenario. At the beginning of $2060 \mathrm{~s}$, precipitation increases by 10,12 , and 12 $\%$ (61, 72, and $72 \mathrm{~mm} /$ year), while evapotranspiration increases by 43,39 , and $32 \%(92,113,124 \mathrm{~mm} /$ year $)$, compared to the end of the 1960s, for climate scenarios IS92c, IS92a, and IS92e, respectively. On the contrary, the streamflow from the basin reduces by 11,14 and $18 \%(31,41,52$ $\mathrm{mm} /$ year) for the scenarios IS92c, IS92a, and IS92e, respectively. 


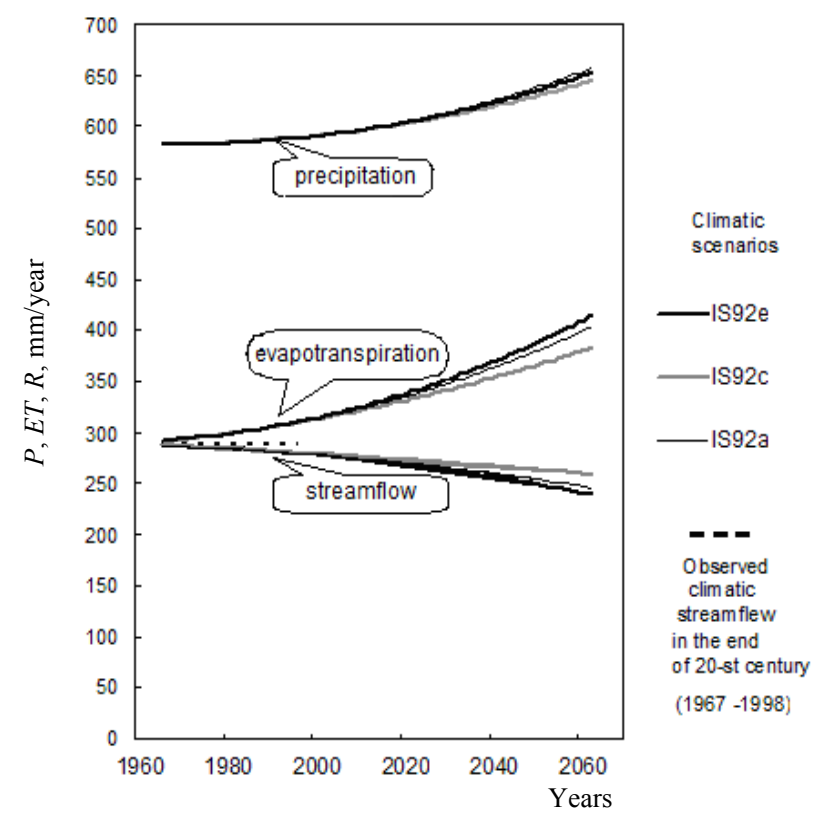

Fig. 4. Evolution of climatic values of precipitation $P$, evapotranspiration $E T$ and streamflow $R$ in the Northern Dvina River basin for three IPCC IS92 climate change scenarios.
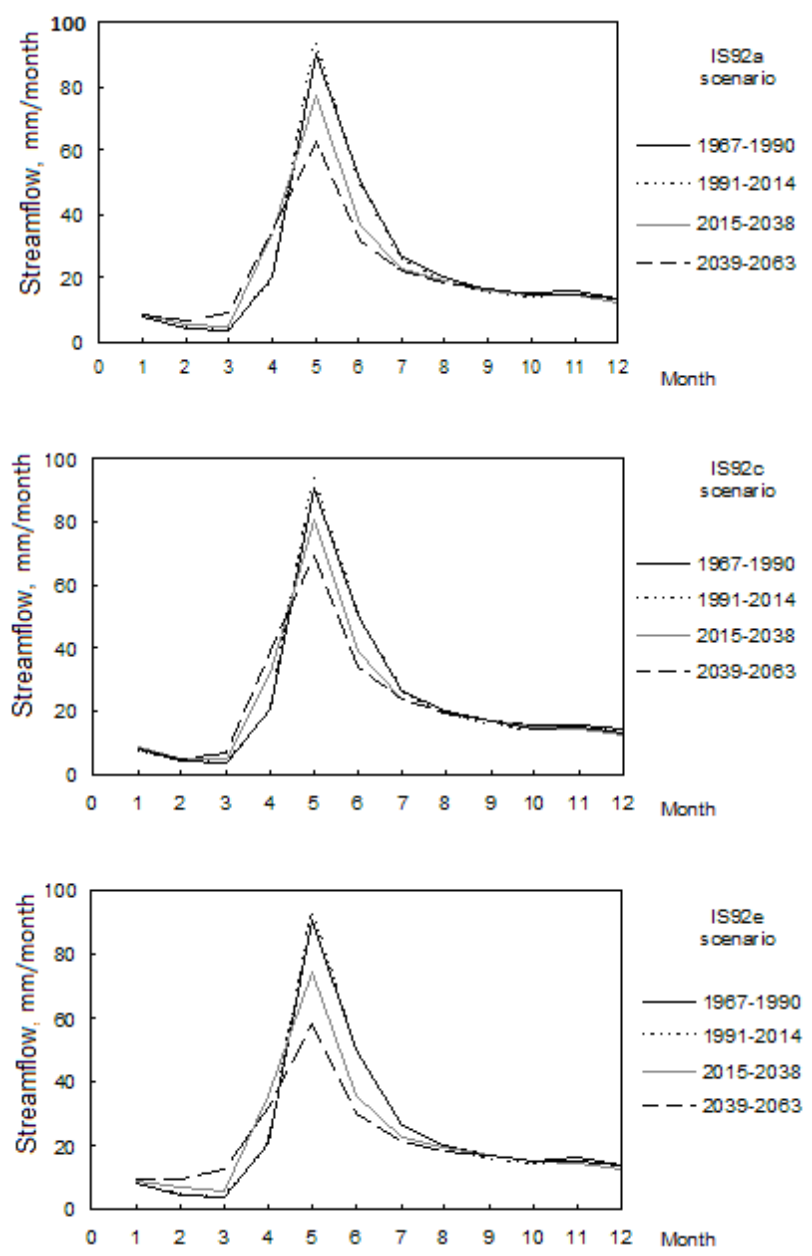

Fig. 5. Change in climatic streamflow hydrographs of the Northern Dvina River for three IPCC IS92 climate change scenarios.

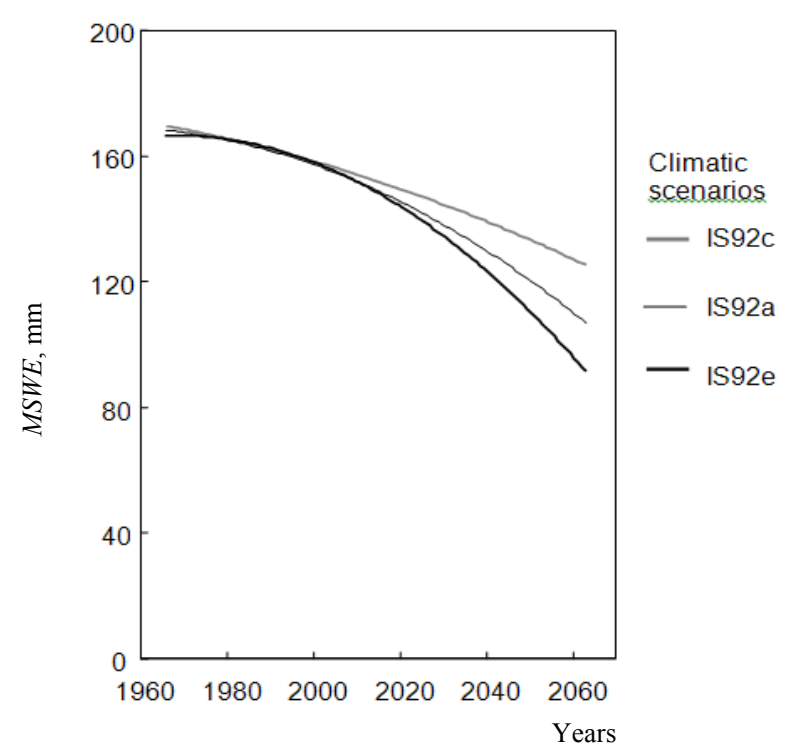

Fig. 6. Evolution of maximum (spring) snow water equivalent (MSWE) over the Northern Dvina River basin for three IPCC IS92 climate change scenarios.

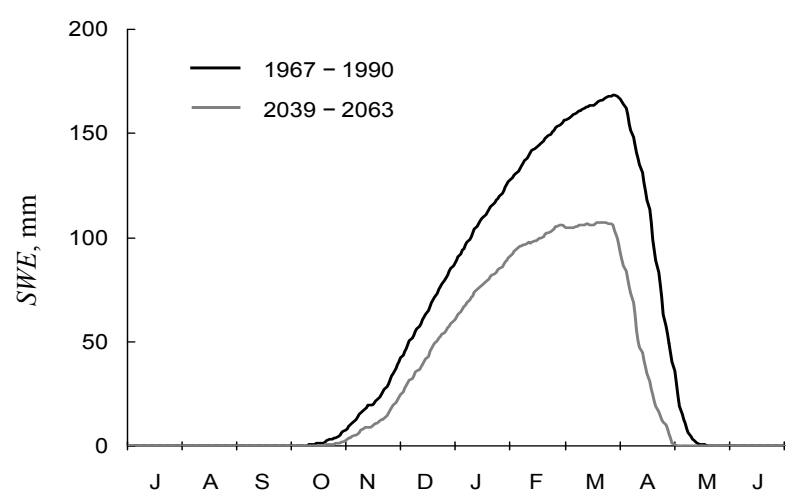

Fig. 7. Climatic (averaged on 24 years) annual dynamics of snow water equivalent accumulation during the base (1967-1990) and the forecast (2039-2063) periods for the IPCC IS92a climate change scenario.

Climate change results in changes of streamflow hydrographs. Figure 5 summarizes the climatic hydrographs for three climate change scenarios and for different periods of averaging. It is seen that the peaks of spring floods reduces, the beginning of the spring flood slightly shifts to earlier dates, the shape of hydrograph becomes more gentle. At the same time winter low flow increases (this is especially noticeable for IS92e scenario). All these phenomena have logical physical explanation. The increase in winter low flow is associated with an increase in the number and the rate of winter thawing caused by increase in the intensity of incoming radiation and, consequently, air temperature. Higher air temperature leads to earlier spring snowmelt. Lowering peaks (and volumes) of spring floods is caused by decrease in maximum (spring) snowpack accumulated during the winter. Figure 6 shows evolution of maximum snow water equivalent (MSWE) up to 2063. By the beginning of 2060s MSWE reduces by 44,62 , and $78 \mathrm{~mm}$ for the scenarios IS92c, IS92a, and IS92e, respectively, as compared to the end of 1960s. 
Latitude, ${ }^{\circ} \mathrm{N}$

(a)

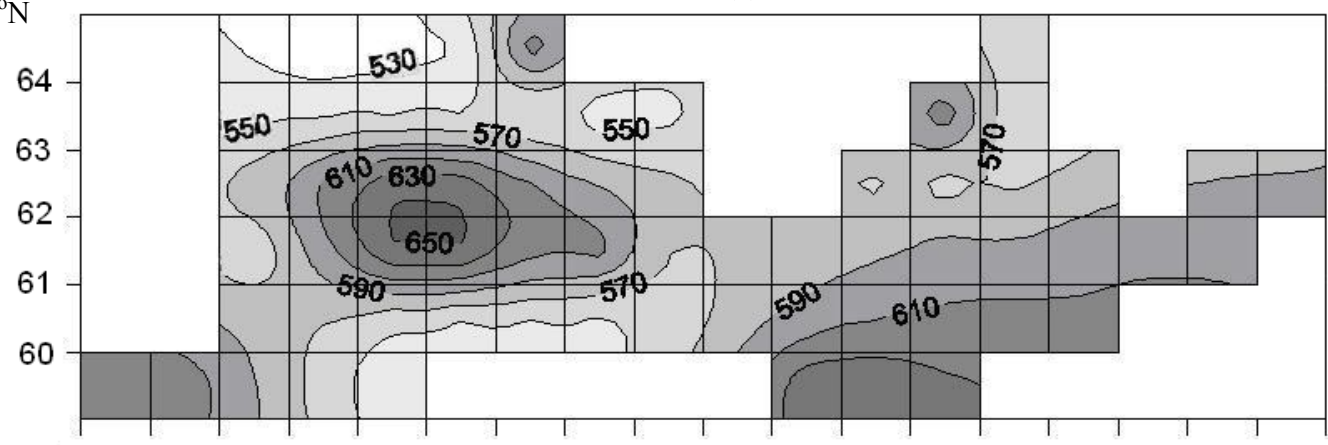

1967-1990

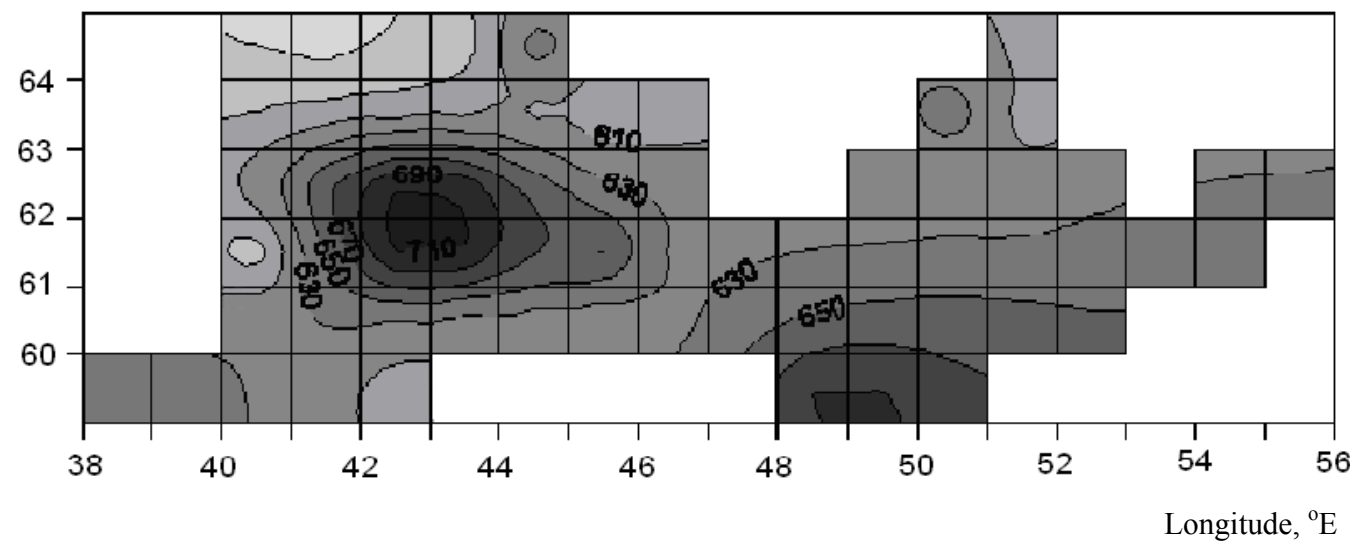

2039-2063

(b)

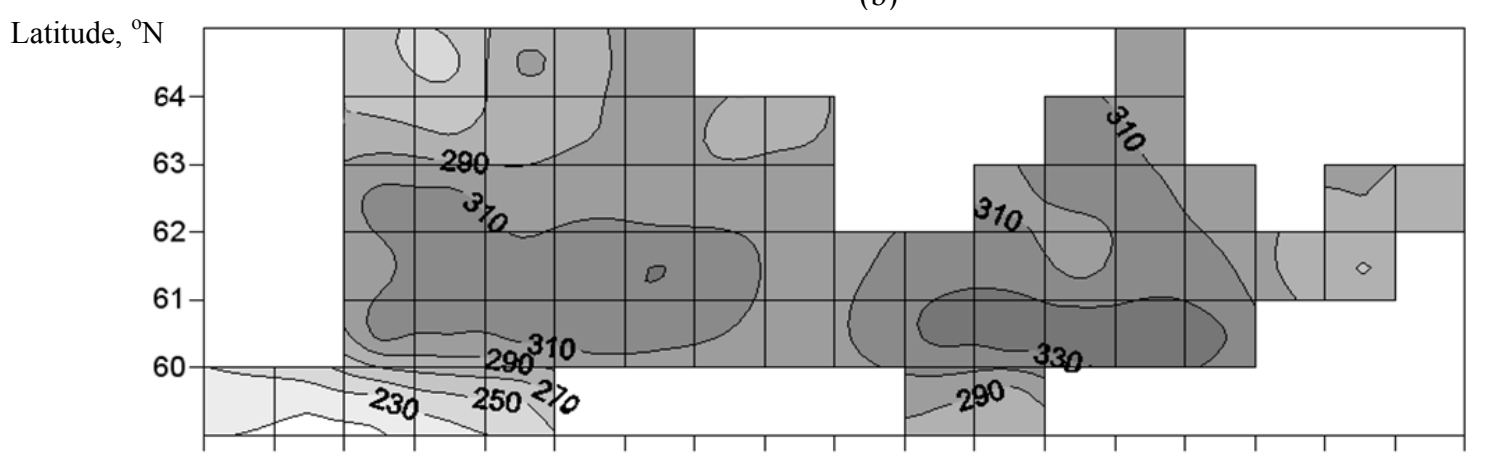

1967-1990

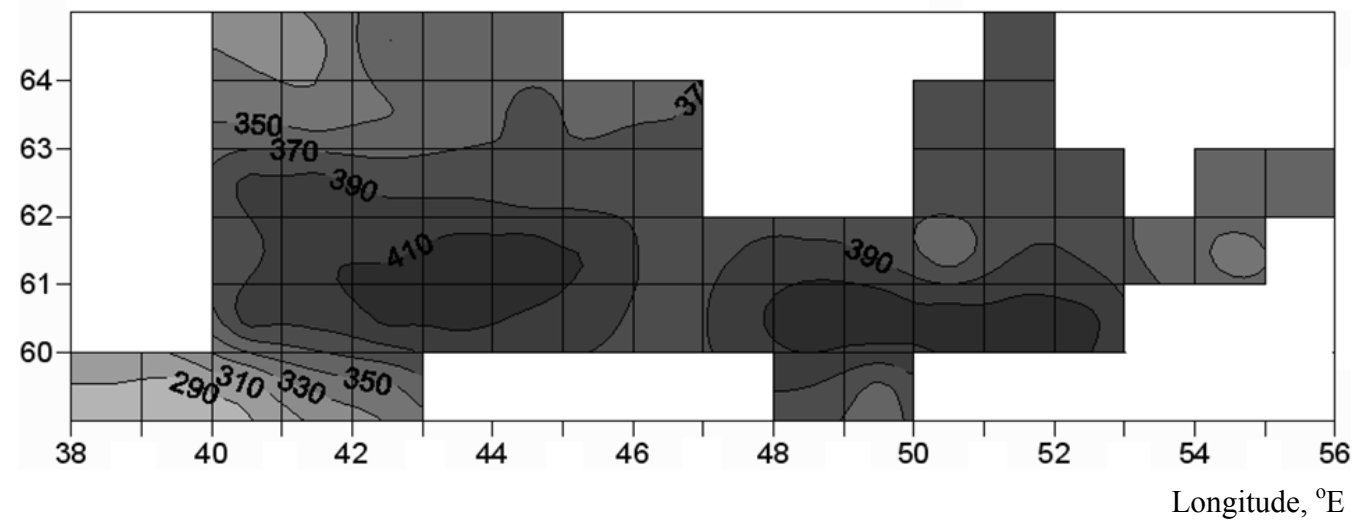

2039-2063

Fig. 8. Spatial distribution of climatic annual values of precipitation (a), evapotranspiration (b) and runoff (c), mm/year, over the Northern Dvina River basin in 1967-1990 and 2039-2063 in accordance with the IPCC IS92a climate change scenario. 
(c)

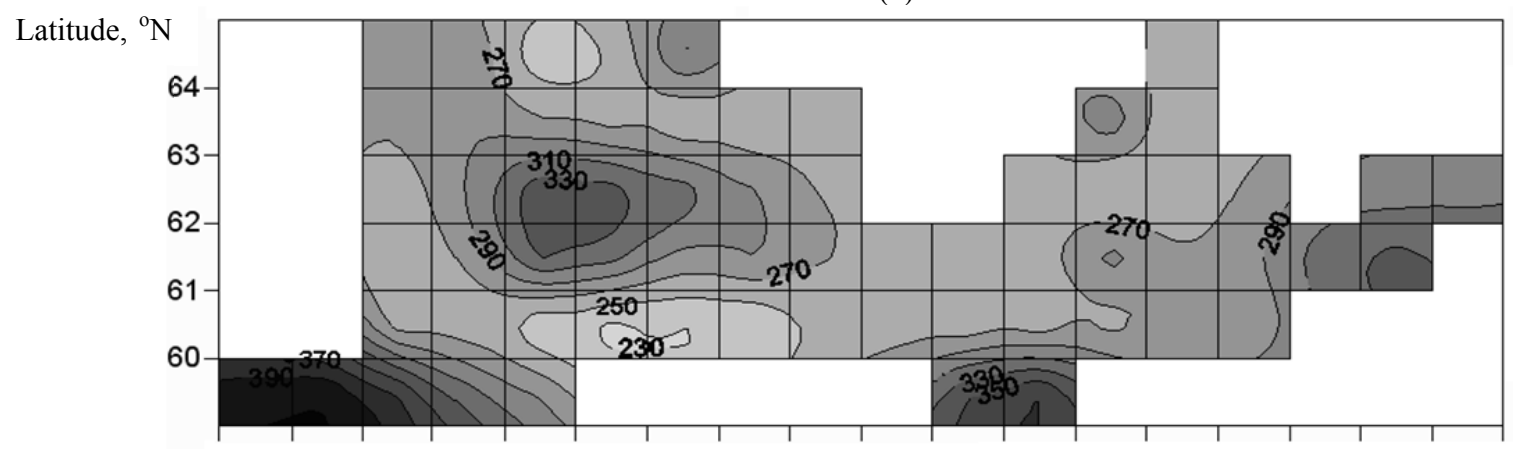

$1967-1990$

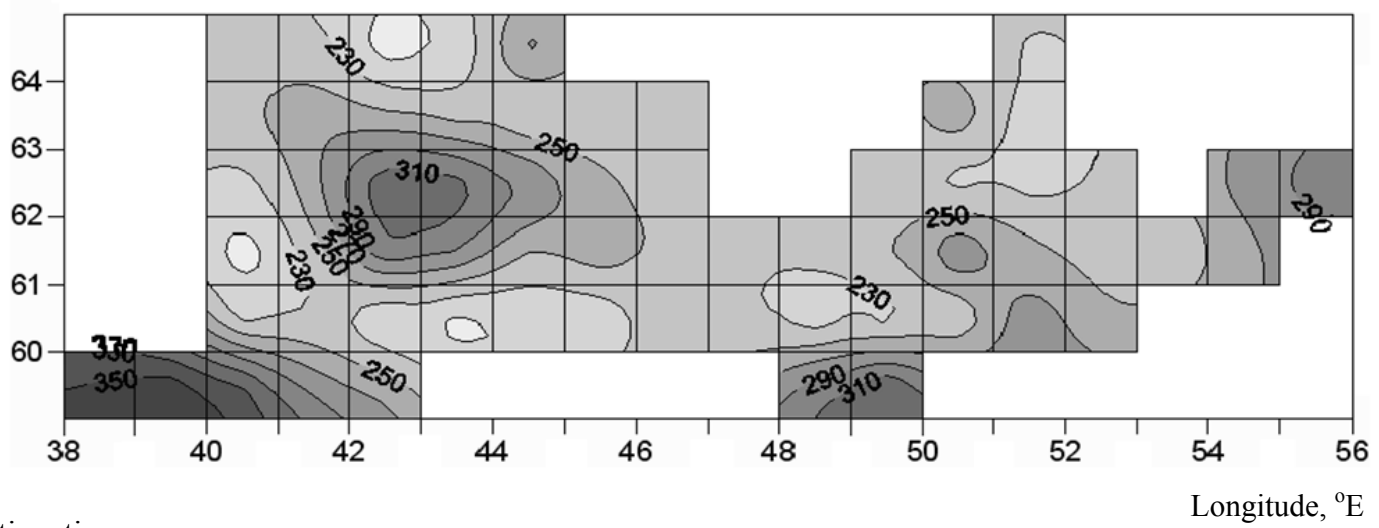

2039-2063

Fig. 8. Continuation.

There are several reasons for such decrease in MSWE. It could be expected that some increase in winter precipitation should result in increase in accumulation of snow, however, the main role is played by the other factors and as a result of their joint influence snow accumulation decreases. These factors are connected with increase in air temperature by 2060 and include a shortening of the cold season duration (thus, transition of air temperature from positive to negative values in autumn will be 7-10 days later, while back transition in spring will be earlier with nearly the same shift), a larger rate of snow evaporation and more frequent winter thaw. All these circumstances result in decrease in accumulation of snowpack within the basin (Figure 7).

Finally, the spatial distribution of climatic values of the water balance components for different periods and climate scenarios was mapped. For example, Figure 8 illustrates changes in spatial patterns of simulated water balance components: precipitation, evapotranspiration, and streamflow (averaged over the two periods of 1967-1990 and 2039-2063) within the Northern Dvina River basin for the "average" (basic) IS92a climate scenario. The obtained spatial patterns, firstly, confirm previous conclusions of the work, secondly, provide an opportunity to evaluate the intensity of changes in the water balance components more locally.

As it was mentioned above, the proposed methodology for projection of changes in the water balance components of the Northern Dvina River basin was also applied to the family of four SRES climate change scenarios (A1, A2, B1, B2) (Nebojsa et al., 2000), used in the third report of the IPCC on assessment of climate change (at its Seventh Conference of Parties of the UN framework Convention, Marrakech, Morocco, November 7, 2001). The obtained results are in a good agreement with those obtained in the present paper using the IS92 family scenarios (compare, for example, Figure 4 of the present paper and Figure 9, taken from (Gusev and Nasonova, 2013)). As seen from Figures 4 and 9 , on the average, the modeled evolution of the water balance components of the Northern Dvina River basin in the first half of the $21^{\text {st }}$ century is similar for IS92 and SRES scenarios. The only difference is a larger scatter in projections of the water balance components in the case of IS92 scenarios, as compared to SRES ones.

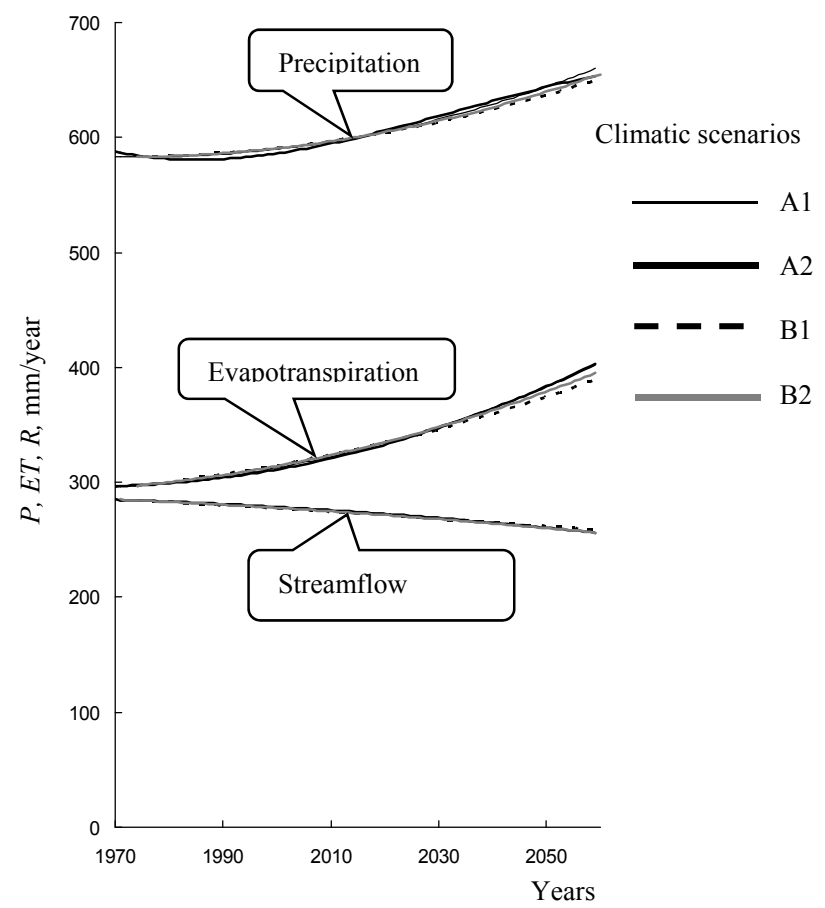

Fig. 9. Evolution of climatic values of precipitation $P$, evapotranspiration $E T$ and streamflow $R$ in the Northern Dvina River basin for the four different scenarios of global climate change according to the IPCC SRES family (Gusev and Nasonova, 2013). 


\section{CONCLUSION}

1. A methodology for scenario projection of changes in the water balance components for northern river basins, caused by possible climate change, is developed. The methodology is based on application of the land surface model SWAP and IPCC climate change scenarios.

2. For three IPCC climate change scenarios: IS92a, IS92c and IS92e, corresponding to different scenarios of economic, technological, political and demographic development of the human civilization, the projected time series (till 2063) of 3hour meteorological characteristics for each calculational grid cell of the Northern Dvina River basin were obtained.

3. On the basis of the obtained scenarios of the dynamics of meteorological characteristics the dynamics of the water balance components of the Northern Dvina River basin up to 2063 was calculated. The values of these components were averaged over 24-25 years to illustrate changes in the components on the climatic scale. It is shown that climatic precipitation and evapotranspiration will increase, while river runoff decrease in accordance with each of the three climate change scenarios. The largest changes are associated with the IS92e scenario, while the lowest with the IS92c scenario. Comparison of the modeled evolution of the water balance components for the Northern Dvina River basin for the family of IS92 climate change scenarios with analogical results obtained for the SRES family (Gusev and Nasonova, 2013) shows that, on the average, the results are very similar.

4. The spatial patterns of changes in the water balance components (precipitation, evapotranspiration, and streamflow) over the Northern Dvina River basin for different climatic periods and climate change scenarios were constructed.

Acknowledgments. The study was supported by the Russian Foundation for Basic Research (project 14-05-0027) the Russian Academy of Sciences (contract 74OK/11-5) and Department of Education and Science (project 14.B25.31.0026).

\section{REFERENCES}

Appolov, B.A., Kalinin, G.P., Komarov, V.D., 1974. Course of Hydrological Forecasts. Gidrometeoizdat, Leningrad. (In Russian.)

Arora, V.K., Boer, J., 2001. Effects of simulated climate change on the hydrology of major river basins. J. Geophys. Res., 106, D4, 3335-3348.

Arora, V., Seglenieks, F., Kouwen, N., Soulis, E., 2001. Scaling aspects of river flow routing. Hydrol. Process., 15, 3, 461-477.

Barry, R.G., Serreze, M.C., 2000. Atmospheric components of the arctic ocean freshwater balance and their interannual variability. In: Lewis, E.L. et al. (Eds): The Freshwater Budget of the Arctic Ocean. Springer, New York, pp. 45-56.

Budagovskii, A.I., 1981. Evaporation of soil water. In: Physics of Soil Water. Nauka, Moscow, pp. 13-95. (In Russian.)

Budagovskii, A.I., 1989. Semiempirical theory of the transpiration and water regime of vegetation. Vodnye Resur., 2, 517. (In Russian.)

Duan, Q., Sorooshian, S., Gupta, V.K., 1992. Effective and efficient global optimization for conceptual rainfall runoff models. Water Resour. Res., 28, 4, 1015-1031.

Field, C.B., Jackson, R.B., Mooney, H.A., 1995. Stomatal responses to increased $\mathrm{CO}_{2}$ : implications from the plant to the global scale. Plant, Cell and Environment, 18, 12141225 .
Gusev, E.M., Nasonova, O.N., 2000. Parameterization of processes of heat and water exchange in the system "soil water soil - vegetation / snow - atmosphere" for territories with a clearly pronounced seasonal climate variability. Pochvovedenie, 6, 733-748. (In Russian.)

Gusev, E.M., Nasonova, O.N., 2004. Modelling the processes of heat and water exchange between the land surface and the atmosphere on a local scale for the areas with permafrost. Pochvovedenie, 9, 1077-1092. (In Russian.)

Gusev, E.M., Nasonova, O.N., 2007. Technique for estimating the dynamics of water and carbon budgets of a coniferous forest ecosystem. Izvestiya, Atmospheric and Oceanic Physics, 43, 1, 70-80.

Gusev, E.M., Nasonova, O.N., 2011a. Modelling Heat- and Water Exchange of the Land Surface with the Atmosphere. Nauka, Moscow. (In Russian.)

Gusev, E.M., Nasonova, O.N., 2013. A technique for scenario prediction of changes in water balance components in northern river basins in the context of possible climate change. Water Resour., 40, 4, 426-440.

Gusev, E.M., Nasonova, O.N., Dzhogan, L.Y., 2006a. The simulation of runoff from small catchments in the permafrost zone by the SWAP model. Water Resour., 33, 2, 115126.

Gusev, E.M., Nasonova, O.N., Kovalev, E.E., 2006b. Modeling the components of heat and water balance for the land surface of the globe. Water Resour., 33, 6, 616-627.

Gusev, E.M., Nasonova, O.N., Dzhogan, L.Y., Kovalev, E.E., 2008. The application of the land surface model for calculating river runoff in high latitudes. Water Resour., 35, 2, 171184.

Gusev, E.M., Nasonova, O.N., Dzhogan, L.Y., 2010. Reproduction of Pechora runoff hydrographs with the help of a model of heat and water exchange between the land surface and the atmosphere (SWAP). Water Resour., 37, 2, 182-193.

Gusev, E.M., Nasonova, O.N., Dzhogan, L.Y., 2011a. Modeling river runoff in northwestern Russia with the use of land surface model SWAP and global databases. Water Resour., $38,5,571-582$.

Gusev, E.M., Nasonova, O.N., Dzhogan, L.Y., Kovalev, E.E., 2011 b. Northern dvina runoff simulation using land-surface model SWAP and global databases. Water Resour., 38, 4, 470-483.

Gusev, Y.M., Nasonova, O.N., 2003. The simulation of heat and water exchange in the boreal spruce forest by the landsurface model SWAP. J. Hydrol. 280, 1-4, 162-191.

Gusev, Y.M., Nasonova, O.N., 2011b. Parameter optimization for simulating runoff from highlatitude river basins using land surface model and global data sets. In: Dritsas, I. (Ed.): Stochastic Optimization - Seeing the Optimal for the Uncertain. InTech, Rijeka, Croatia, pp. 413-440.

Houghton, J.T., Ding, Y., Griggs, D.J., Noguer, M., van der Linden, P.J., Dai, X., Maskell, K., Johnson, C.A. (Eds.), 2001. Climate Change 2001: The Scientific Basis. Contribution of Working Group I to the Third Assessment Report of the Intergovernmental Panel on Climate Change. Cambridge University Press, Cambridge and New York.

Leggett, J., Pepper, W.J., Swart, R.J., Edmonds, J., Meira Filho L.G., Mintzer, I., Wang, M.X., Watson, J., 1992. Emissions Scenarios for the IPCC: an Update. Climate Change 1992: The Supplementary Report to the IPCC Scientific Assessment. Cambridge University Press, UK.

Liston, G.E., Sud, Y.C., Wood, E.F., 1994. Evaluating GCM land surface hydrology parameterizations by computing riv- 
er discharges using a runoff routing model: Application to the Mississippi Basin. J. Appl. Meteorol., 33, 394-405.

Lozinskaya, E.A., 1988. Method and results of determining the parameters of a model of evapotranspiration. Vodnye Resur., 4, 17-23. (In Russian.)

Maherali, H., Reid, C.D., Polley, H.W., Johnson, N.H.B., Jackson, R.B., 2002. Stomatal acclimation over a sub-ambient to elevated $\mathrm{CO}_{2}$ gradient in a $\mathrm{C}_{3} / \mathrm{C}_{4}$ grassland. Plant, Cell and Environment, 25, 557-566.

Matveev, L.T., 1979. Course of General Meteorology. Atmospheric Physics. Gidrometeoizdat, Leningrad. (In Russian.)

Meleshko, V.P., Golitsyn, G.S., Govorkova, V.A. et al., 2003. Possible anthropogenic changes in the climate of Russia in the $21^{\text {st }}$ century: Estimations from an ensemble of climate models. In: Proceedings of World Conference on Climate Change, Inst. Glob. Climate and Ecology, Moscow, pp. 5152. (In Russian.)

Meleshko, V.P., Golitsyn, G.S., Govorkova, V.A. et al., 2004. Possible anthropogenic changes in the climate of Russia in the $21^{\text {st }}$ century: Estimations from an ensemble of climate models. Meteorol. Gidrol., 4, 38-49. (In Russian.)

Miller, J.R., Russell, G.L., 1992. The impact of global warming on river runoff. J. Geophys. Res., 97, 2757-2764.

Model for the Assessment of Greenhouse-gas Induced Climate Change, 2000. Concepts and Design: Wigley T.M.L., Raper S.C.B., Hulme M., Salmon M. Model Development and Scientific Programming: Wigley T.M.L., Raper S.C.B., Osborn T.J. Graphical User Interface: Salmon, M. Published by the Climatic Research Unit, University of East Anglia, Norwich, UK and the National Communications Support Programme, UNDP / GEF, New York.

Nash, J.E., Sutcliffe, J.V., 1970. River flow forecasting through conceptual models: 1. A discussion of principles. J. Hydrol., $10,3,282-290$.

Nebojsa, N., Alcamo, J., Davis, G., De Vries, B., Fenhann, J., Gaffin, S., Gregory, K., Grübler, A., Tae, Y., Kram, T., LA
Rovere, E.L., Michaelis, L., Mori, S., Morita, T., Pepper, W., Pitcher, H., Price, L., Riahi, K., Roehrl, A., Rogner, H., Sankovski, A., Schlesinger, M., Shukla, P., Smith, S., Swart, R., van Rooijen, S., Victor, N., Dadi, Z., 2000. IPCC Special Report on Emissions Scenarios: A Special Report of Working Group III of the Intergovernmental Panel on Climate Change. Cambridge University Press, Cambridge.

Nohara, D., Kiton, A., Hosaka, M., Oki, T., 2006. Impact of climate change on river discharge projected by multimodal ensemble. J. Hydrometeorology, 7, 1076-1089.

Pepper, W.J., Leggett, R.J., Swart, R.J., Watson, J., Edmonds, J., Mintzer, I., 1992. Emission Scenarios for the IPCC: An Update, Assumptions, Methodology, and Results. US Environmental Protection Agency, Washington.

Pivovarova, Z.I., 1977. Radiation Characteristics of Climate of the USSR. Gidrometeoizdat, Leningrad. (In Russian.)

Polley, H.W., Johnson, H.B., Mayeux, H.S., 1997. Leaf physiology, production, water use, and nitrogen dynamics of the grassland invader Acacia smallii at elevated $\mathrm{CO}_{2}$ concentrations. Tree Physiology, 71, 89-96.

Shmakin, A.B., 1998. The updated version of SPONSOR land surface scheme: PILPS-influenced improvements. Global Plan. Change, 19, 1-4, 49-62.

Wilby, R.L., Wigley, T.M.L., 1997. Downscaling general circulation model output: a review of methods and limitations. Progr. Phys. Geogr., 21, 530-548.

WMO, 1994. Guide to Hydrological Practices. WMO No.168. World Meteorological Organization, Geneva.

Zhao, M., Dirmeyer, P., 2003. Production and Analysis of GSWP-2 near-surface meteorology data sets. COLA Technical Report No. 159. Center for Ocean-Land-Atmosphere Studies, Calverton.

Received 12 September 2012 Accepted 17 March 2014 